MARian GORYNia

Poznań University of Economics, Poland

m.gorynia@ue.poznan.pl

ORCID iD: 0000-0002-7633-8249

PRZEMYSŁaW DESZCZYŃSKI

Poznań University of Economics, Poland

przemyslaw.deszczynski@ue.poznan.pl

ORCID iD: 0000-0003-2286-3395
PIOTR BANASZYK

Poznań University of Economics, Poland

piotr.banaszyk@ue.poznan.pl

ORCID iD: 0000-0002-9457-3613

Krzysztof MalaGa

Poznań University of Economics, Poland

krzysztof.malaga@ue.poznan.pl

ORCID iD: 0000-0001-7079-9880

\title{
POTENTIAL AND DESIRED CONSEQUENCES OF THE COVID-19 PANDEMIC FOR RESEARCH IN ECONOMIC SCIENCES ${ }^{1}$
}

\section{SUMmaRY}

The authors posit the need for the modification or even revision of how economic sciences (ES) are practiced in ontological, epistemological, and methodological aspects. The need results from the impact of several factors that appeared even in the pre-pandemic period, for which Covid-19 may be a complementary and reinforcing circumstance that may even directly determine the change. The structure of the article follows its goal, which is the author's reflection on the main thesis. To this end, the author's selected four issues to exemplify the areas that require change, for which they propose a set of postulates that constitute the desired modifications in ES. The main method we used was that of critical literature analysis and desk study - as for the scientific approach this article uses a qualitative design of research.

KEYWORDs: economics, economic concepts, economic sciences, economic paradigms, the Covid-19 pandemic, evolution of economic sciences, global supply chain, international competitiveness, globalization, development economics

JEL CLASSIFICATION CODES: A10, A11, A12, B1, B2, B4, B5, C1, D6 


\section{INTRODUCTION}

Socio-economic life does not develop in a linear manner. Over time, various phenomena accumulate and mutually reinforce each other, the interaction of which at some point reaches a critical point and causes a qualitative change. ES usually emphasize the importance of economic crises, which are of such groundbreaking nature and stimulate a change in the practice and paradigm of its research and explanation.

Currently, the global community is in the period of the so-called pandemic crisis. The SARS-CoV-2 coronavirus pandemic is itself a factor that is seriously affecting the state of the global economy. However, it is not the only factor. Equally significant factors are the progressive global warming, forcing economic processes to shift to zero-emission paths, social unrest and migrations caused by the increasing income and property stratification, pressure resulting from the increasingly important use of information and communication technologies leading to the so-called economy 4.0 , etc.

Taking into account the processes outlined above, we make the thesis that continuing the socio-economic life on the basis of principles and methods that in the past guaranteed rapid economic growth and spectacular business successes are no longer satisfactorily effective. Since a radical change in economic policy and business practice is necessary, the approach and research methodology in ES should also change, which means the need to change the paradigm of these sciences. It is worth remembering that the task of ES is to model economic and business processes, because ES have both a cognitive-explanatory (positive) and directive-suggestive (normative) component. The latter component are patterns and recommendations related to the economic and business reality, and they should be different from those known from the past and to a large extent still practiced in the present.

The aims of this article are twofold. First, by citing a few examples, we strive to justify the thesis presented above. Secondly, we are trying to invite representatives of various research centers in the field of ES to discuss the directions of paradigm revision of these sciences. The content of the article does not aspire to a complete elaboration of this new paradigm, nor to exhaustively present the reasons for this need. The intention is not, of course, to depreciate the achievements of ES to date, because in the past, 
the economic theories formulated and pushed for truly explained the economic and business realities of the time and indicated the desired methods of economic and business activity. However, economists are familiar with the phenomenon known as strategic surprise. For psychological reasons, it is very difficult to give up the views that have earned recognition and a prestigious scientific status. Historical scientific achievements as well as their authors and supporters cannot be disregarded. May the observation that scientific paradigms go down in history with the cessation of scientific activity by their promoters does not come true.

This article discusses four sample research areas from ES. Namely, they are global supply chains, international competitiveness, globalization and development economics. The study perspective is therefore focused on the international aspects. Global supply chains are a phenomenon of recent decades and remain associated with the intensification of relocation of production centers and the strategy of foreign direct investment. The conviction about the need to create national wealth in each country results, on the one hand, in creating conditions by their governments that are intended to be a magnet in relation to these investments, and on the other hand, in leveraging the competitive position of domestic enterprises on the global market. A specific buckle of the above processes is economic globalization, which, however, provokes various social and political effects, which are the domain of development economics. Of course, these four research areas do not exhaust the issues raised in the article. Besides, the authors have already published articles describing other research areas.

From the methodological point of view, each of the indicated research areas is analyzed on three levels. These are ontological, epistemological and methodological levels, i.e. facts, ways of perceiving them, and methods of research and stimulation are presented. In each of these areas, we try to indicate how it is and how it should be (sometimes also how it shouldn't be). 


\section{THE PERSPECTIVE OF MODIFYING THE PARADIGM OF ECONOMIC SCIENCES}

Economic sciences are part of the set of applied social sciences. This fact complicates research projects undertaken in their field. If we assume that in the course of research efforts it is necessary to solve three types of problems, namely cognitive, axiological and normative (Sławińska, Witczak, 2008: p. 72), then it is not enough to describe economic and business processes and explain them. Resolving cognitive problems requires examining the processes in question, systematizing them and explaining them. In this way, knowledge of reality is gained. The social nature of ES causes that the researcher, with a sense of responsibility towards society (towards humans), faces axiological problems that require evaluation in terms of both efficiency and ethics. When it is known how and why economic and business processes take place and how permitted and useful their effects are, a normative problem appears - what to do to make it better (more efficiently, more effectively, more correctly). As a consequence, knowledge about economic and business realities is accumulated in ES, which thanks to this knowledge are constantly modified. Therefore, the subject of research is constantly changing, falsifying the existing arrangements and directives. Therefore, it is constantly striving to identify new phenomena (ontology), assess their significance (axiology), propose better methods of understanding them (epistemology) and formulate new guidelines for action (methodology).

The presented complication justifies the existence of different views and research methods pushed by various research centers and their representatives. By the nature of things, therefore, ES have and should have a multi-paradigmatic character (Fiedor, 2018; Gorynia, 2019a, 13-40). There will be no progress in ES without a substantive discussion by advocates of different research paradigms. Undoubtedly, however, at a given time, one of these research patterns has a dominant character, because it is shared by the majority of researchers. In recent years, ES have been dominated by the so-called economic orthodoxy equated with the neoclassical school (Colander et al., 2003, p. 5). Its most important assumptions include: 
a) common microeconomic rationality explained by the homo economicus model,

b) tendency to general and partial equilibrium,

c) mathematical formalism (Fiedor, 2019, p. 49).

With regard to economic and business processes, this paradigm created a specific logic of action. Constant increase in production, thanks to which GDP grows and allows for richer consumption. This is the description of reality, the explanation of the cause and effect relationships and, consequently, a positive assessment and an unambiguous directive of conduct. However, production requires more and more intensive exploitation of natural resources and creates many negative economic externalities and requires forced and excessive consumption. The accumulation of these phenomena and the emerging increasingly intense threats require a change in this way of thinking, i.e. a change in the current paradigm in ES.

It is therefore worth analyzing and evaluating the various sub-areas explored by ES in order to propose new insights and new proposals for the evaluation and shaping of economic and business processes.

\section{THE DESCRIPTIVE-EXPLANATORY VERSUS NORMATIVE CHARACTER OF ECONOMIC SCIENCES}

A matter frequently raised in discussions concerning the crisis caused by the Covid-19 pandemic is the character of economics and, more broadly, economic sciences in terms of the functions they perform. The result of centuries of reflection on this issue brought no unequivocal solutions. We can distinguish two different positions in this regard: a) a position that promotes a positive approach, b) a position that leans toward the active and normative involvement of economic sciences in creating/fixing reality. Both refer to the concepts of constructivism (constructionism), pragmatism, and new pragmatism.

The positive approach primarily assigns economic sciences with the descriptive-explanatory function (Lipowski, 2011). In this view, science should be devoid of evaluative and normative elements. One of the precursors of such an understanding of the function of science may be considered David Hume, who stated that we should not derive value judgments from descriptive judgments 
of facts ("Hume's guillotine;" Hume, 1969, p. 469). Lionel Robbins (1932) and Milton Friedman (1953) shared this view. The knowledge of how reality works may be useful at most for forecasting - i.e. predicting the future - but it should not be used for reality's creation in the sense of setting goals. However, it is hard to resist the impression that one cannot fully defend such an approach. If descriptive and explanatory knowledge show that the use of certain tools of economic policy are highly likely to lead to negatively assessed effects, then such knowledge results in a recommendation not to use these tools. However, this is a different situation than creating goals for socioeconomic development, and in this sense, it appears to fall within the framework that Lionel Robbins envisaged for economic sciences. Setting goals and selecting methods or means to achieve these goals are two different things.

The normative approach recommends a broader range of using economic sciences - both for setting development goals and defining the means to achieve them (Krugman, 2020). In this case, Max Weber's notion of rational action, in which the adoption of a particular intention is accompanied by the selection of means and consideration of side effects. A contemporary version of this approach is Gregory W. Kołodko's notion of new pragmatism (Kołodko, 2014; 2020b; Gorynia, 2019a).

In discussions about the post-Covid-19 economy, experts emphasize the need for a broader use of scientific achievements - including economic sciences - to shape reality in such a way as to minimize the likelihood of similar pandemics and crises they cause. Some indicate that the accumulation of factors negatively affecting the development of human civilization has reached unprecedented proportions, and this alone justifies the need for the use of science to rationalize civilization (Solarz, Waliszewski, 2020). Indeed, in reality the range of problems that require a solution is very wide, which we will signal below (points 4-11). Their cognition and explanation are essential as it is on them that the economic sciences research efforts should focus in the ontological-epistemological sense. In the sphere of ontology and epistemology, the great complexity and intricacy of relationships among components of civilization requires a comprehensive, holistic, and multidimensional approach. In this view, we should broaden the scope of empirical research to explain economic reality, especially in the area of modern civilization's 
shortcomings and the resulting crises. The sphere of methodology requires us to adopt a pragmatic approach, oriented toward solving specific problems, whose essence should be the focus of researchers' attention, without fixed assumptions that characterize specific schools of philosophy and dependence on a particular class of methods (Creshwell, \& Creshwell, 2018). In other words, we recommend eclecticism and pluralism in an individual choice of methods. Such understood, pragmatism remains open to various visions of the studied world, diverse research assumptions, and various forms of data collection and analysis. Therefore, we may expect an increase in the role of methodological triangulation, which implies a parallel flexible use of research methods that should complement each other and contribute to the better recognition of cause-and-effect relationships in economic activity. However, let us highlight the troublesome limitations of economic sciences. First limitation regards their multi-paradigmatic character, namely the coexistence of various notions, which some interpret as evidence of the underdevelopment of these sciences, while others as an expression of the complexity of the socioeconomic system (Gorynia, 2019a). The second limitation is related to the fact that the economic aspect is only one of the many dimensions of civilization, so its understanding and recommendations' construction in relation to practice should be multidimensional, considering the entirety of systemic properties. The third and final limitation is the difficulty of building economic forecasts based on theory, as signaled by e.g. Karl Popper, Oskar Morgenstern, Robert Lucas, or Robert Merton (Dzionek-Kozłowska, 2018, p. 174-175). These difficulties may be viewed as premises for a constructive exchange of ideas among different schools of economic sciences and even among various disciplines or fields of study.

Thus, on the one hand, the demand for socioeconomic practice in economic knowledge necessary for the rationalization of civilization seems to be high and increased as a result of the pandemic. However, on the other hand, what hinders the rationalization of civilization is the influencing of economic reality with the use of ambiguous results of theoretical and practical research, many of which are objective in nature. In this situation, it seems to us that what may be a useful measure is even the most basic education of societies in the cardinal and unquestionable rudimentary mechanisms of economic life. We might 
risk a statement that changes in science should necessarily be accompanied by changes in education. Indeed, the former is not enough. In general, we may recommend that - in the face of pluralism and imperfections in created notions - we should follow a heterodox rather than an orthodox approach in education.

\section{GLOBAL SUPPLY CHAINS}

A supply chain is a collective of companies gathered along a vertical technological and operational process - or, as some claim, along the process of adding value to successive business outcomes - starting from the sourcing of raw materials and ending with the transfer of products to final consumers (Mentzer et al. 2003, p. 3; Snyder, Shen, 2019, p. 1; Witkowski 2010, p. 19). At the turn of the twentieth and twenty-first centuries, supply chains became a tool for building competitive capabilities in a globalized economy. Managers in companies have been forced to compete increasingly by reducing their own costs, shortening the time of service to the buyer, and maintaining the highest quality of products. This required the use of special instruments such as supply chains (Mentzer et al., 2003, p. 2).

The opportunity to build attractive competitive potential thanks to global supply chains results from the three following reasons. First, the global supply chains are created through outsourcing, i.e. focusing economic activity on their most efficient part for a given company and using the activity of other companies that are more efficient in other necessary parts of economic activity (Langford, Parsa, 1999, pp. 310-316; Trocki, 1999, pp. 181-183). Second, global supply chains gain stability thanks to Williamson's effect of asset specificity. Asset specialization may concern both human resources and other, inanimate resources. In a situation when specialized assets are used, partners become bilaterally dependent, and what falls are not only transformation (production) costs but also recipient change costs, if the cooperation is planned for a long term so that the supplier simply need not include the cost of changing the recipient (Wilkin, 2016, pp. 198-199). Third, supply chains become global because the liberalization of international political and economic relations allows for the intensification of trade and the international localization of 
companies, which the "new new theory of international trade" is currently trying to explain (Dzikowska, 2017, pp. 49-52).

The disruptions revealed and caused by the pandemic are a change at the ontological level. This is because real supply chains and networks are being transformed, particularly in economic sectors judged to be crucial to health security and the decision-making autonomy of societies and national governments. Zahn et al. (2020) indicate that in result of the pandemic, real supply chains will be shorter and more geographically compact, while global supply chains will become more diversified in terms of location; the more so that the drivers of their agility will cease to be physical assets and will be electronic platforms, while the regionalization of supply chains will shorten physical assets but will not change their fragmentation.

The above transformations are becoming increasingly evident (epistemological aspect) and are gather support for different supply chain management principles and methods. The Covid-19 pandemic has shown how global supply chains are not immune to disruption. It seems untenable for a global supply stream to be dependent on a small number of geographic locations. For example, $40 \%$ of the electronics industry's supply and $80 \%$ of the pharmaceutical industry's supply comes from China (Marsevich, 2020). It is important to emphasize that the pandemic not only temporarily interrupted production at suppliers but later also froze transportation capacity in many intermediate countries, so as to finally - after the economies thawed - became the cause of both transportation and throughput congestion in major logistics hubs. Supply chains for many products focus on optimizing efficiency at the expense of security and reliability. The popular Just in Time management method liquidates inventory, which seems unsustainable if security and reliability are prioritized (Knapp, 2020). Economic and political pressure to change this state seems to be a natural reaction. Simply continuing with "hyperglobalization" is unsustainable because of its immanent contradiction with democracy and the sovereignty of states (Rodrik, 2011).

The pandemic is only one factor of the change. Others include technological advancement, rising political tensions, and the heightened importance of national interests. In sum, these factors cannot be ignored by economic sciences. The need for a revision of prevailing theoretical notions becomes apparent. 
Of course, this has to do with the shift from EVA to economic resilience and how it forces the development of new concepts of international trade and international production (international business location) and directives (principles) on the management of global supply chains. Propositions of a concept explaining the need for change appeared earlier. Among them, we may indicate Richard D'Aveni's (1995) idea of hypercompetition and Jeremy Rifkin's (2016) zero marginal cost society. The conclusion has always been the same: old business management and theoretical arrangements cannot or should not be sustained in the changed reality.

It can be assumed that the process of globalization will get complicated. Probably some sectors will not be changed. By contrast, the production of sanitary and strategically sensitive goods may be marked by a move away from globalization.

\section{INTERNATIONAL COMPETITIVENESS}

Unfortunately, the concept of international competitiveness does not have a universally accepted definition. In the approach emphasizing locational attractiveness and the quality of management, many recognize that the ability to compete internationally depends on the competitive potential of enterprises in product markets, the potential of geographic areas and whole countries to attract mobile factors of production, and on the state of immobile factors of production, particularly the level of labor costs and job protection policies (Mitschke, 2008, p. 108). The character of international competition understood in this way can be reduced to the interaction of institutional mechanism (formal-legal conditions and the economic policy of administrative authorities) and the competitive mechanism of enterprises (competition). Michael Porter (2011, pp. 71-73) promotes a slightly different view, which shows international competitive ability at the industry level to first depend on the enterprises' strategy, structure, and competition method, second - on the determinants of the factors of production, and third - on demand conditions, and fourth - on related and supporting industries. These factors determine international competitive ability, modified by random circumstances and 
government policies. This concept is often referred to as the Porter's Diamond Model (Gorynia, 2019c).

Satya Dev Gupta (2015, pp. 9-22) proposes an explanation of international competitiveness through the interaction of two diamonds. The first links the characteristics of the industry (sector) determined by the reinforcing function of national economic policy, the quantity and quality of physical and human resources, the technological level, economies of scale, the state of supporting industries, and demand factors related to the size of domestic market. The second diamond refers directly to enterprises and is determined by the resource and competence ability to transform comparative advantage into competitive advantage, innovation strategies related to supply factors and supporting industries, innovation strategies related to demand factors and product differentiation, along with business environment and government policies.

The Covid-19 pandemic changes the above realities (the ontological aspect) and reveals additional factors of international competition (the epistemological aspect).

The experience of the pandemic caused by the SARS-CoV-2 virus highlights the importance of the security factor, which includes sanitary and workplace security. An additional observation is related to the confrontation of remuneration levels of various professional groups according to the hierarchy of their social importance. The notion of essential workers, whose performance proves particularly important in emergency situations, has become widespread (Disaster management 2020). This issue is closely related to dominant axiological systems, i.e. it touches upon the issues of economic and organizational culture. Thus, we may conclude that just as Porter's Diamond was supplemented by Gupta's Diamond, we now obviously require to add a third diamond of a cultural (axiological) nature. The postulated concept of international competition should consist of three mechanisms. First is the sectoral mechanism (explained by Porter), second - the innovation stimulation mechanism (explained by Gupta), and third the axiological-cultural mechanism (awaiting explanation). We may think that advantage in international competition will be gained by those who besides traditional conditions - will also meet the condition of treating and 
rewarding workers fairly because of their actual usefulness in relation to the formation of subjective wellbeing in the society.

This additional component enriches the set of principles and directives for the formation of international competition of enterprises, i.e. it touches upon methodological issues of building their competition and at the same time requires appropriate methodological solutions of their cognition and explanation.

\section{GlobalizAtion}

In the economic sense, globalization (mundialization) may be treated as a special case of the internationalization of economic cooperation, characterized by the following features:

a) in its essence, globalization is a logical consequence of the existing development of market economy and a natural stage of its evolution, which means it is immanent and unavoidable;

b) the intensity, universality (global reach), uniformity, unification, and standardization of actions on a world scale are the basic attributes of the globalization participants;

c) globalization is a higher (the highest?) stage of internationalization;

d) the most important manifestations of globalization are international trade (exports, imports), foreign direct investments, international financial (capital) markets, with the role in this process played by information technology and the Internet (Gorynia, 2019c).

Noteworthy, there are large discrepancies in the understanding of globalization, especially the possible perceptions of globalization in the category of opportunities, threats, and its effects. From this viewpoint, the extensive literature on the subject (Al-Rodhan, Stoudmann, 2006; Kowalski, 2013) reveals four basic attitudes in the understanding of globalization: an approach dominated by enthusiasm slightly cooled by reason that can be described as pro-globalization or affirming globalization (but not blindly; Bhagwati, 2004); an approach of concerned reflexivity, characterized by the balanced understanding of the nature of globalization (Streeten, 2001); an approach 
imbued with a high degree of suspicion, strongly critical but without outright negation (Stiglitz, 2002, 2007); an approach that involves questioning the meaning of globalization, manifested in ideas and policies described as new protectionism and new nationalism (e.g. the actions of President Donald Trump's administration and of similar leaders; Rodrik, 2017).

From the perspective of Poland, we should note that economic globalization intensified after the fall of the Iron Curtain. From an economic standpoint, it meant the liberalization of international economic and political relations and the opening of the opportunities for the integration of previously independent markets of goods, capital, and labor into a single global market (Kołodko, 2003, p. 27). As time passed, not only the benefits of globalization were becoming clear but also its negative effects. Stiglitz $(2002,2007)$ highlights such negative features of globalization as unfair rules of the game imposed by the more powerful developed countries, the uneven distribution of globalization benefits, losses of some participants in the process, imposing of an economic system inappropriate for the traditions, culture, and developmental challenges of many developing countries. Some studies even indicate that economically developed countries gain more than they lose from economic globalization, while developing countries lose rather than gain (Walas-Trębacz, 2007, pp. 59-62).

The reputation of globalization was further undermined by emerging crises. Existing solutions were perceived as dogmatic and incapable of resolving emerging conflicts on internal and international levels. Many progressively lost faith in the reliability of neoliberal solutions in the spheres of economics (the undermining of the Washington Consensus) and politics (the functioning of liberal democracy; Stiglitz, 2002, Rodrik, 2011, 2017).

One of the consequences of the global financial crisis of 2007-2011 was the emergence of symptoms of a process described as "slowbalization" (meaning slow globalization; The Economist, 2019). The process of deglobalization thus occurred before the Covid-19 pandemic (Gorynia, 2020). The difference resides in the new element of fear that future highly probable pathogens may cause rapidly spreading incurable diseases, which makes many expect the petrification of the deglobalization tendency in all the spheres that are synonymous with the broadly understood security of the state and its citizens. Considering the above, there must happen a redefinition of economic 
efficiency from short-term to long-term, and the abandonment of low prices primacy and the ensuing lack of diversified supply. What best exemplifies these matters are the problems with purchasing and manufacturing medicines in Europe, even before the outbreak of the pandemic, and then after the appearance of the coronavirus on the continent, ranging from simple personal protection equipment through disinfectants to specialized equipment such as medical ventilators. However, it remains an open question how deep the deglobalization will be and whether the opponents of neoliberal solutions in economic, political, and social systems would not want to take advantage of this objective situation to introduce and, perhaps, even impose their preferred solutions, motivated only by subjective and axiological rather than pragmatic considerations? This, however, appears to us as a rather a rhetorical question.

When it comes to the projected consequences of the Covid-19 pandemic in the sphere of globalization and the balance of economic power in the world, we encounter a plethora of views in the literature, which encourages various authors to build possible scenarios for the future of globalization (Gorynia, $2020,2021)$. On the one hand, some indicate that, "[g]lobally, China is recovering from the pandemic relatively better than the USA, because it has managed to avoid a recession and is rapidly returning to the path of above-average growth" (Kołodko, 2020a). On the other hand, others remark that China's role as the factory of the world may diminish. This is important because with the passage of time, there increases the probability of social unrest in China and, in consequence, a socioeconomic and political crisis. If this were to happen, it would have a disastrous impact on the global economy, given the current high dependence on Chinese supplies. If the pessimistic scenario comes true, the geography of globalization will change.

From an ontological perspective, the caesura of the Covid-19 pandemic may serve as a starting point for a change in the essence of economic processes. This change consists in the diminishing of the role of an important factor that intensifies economic globalization: consumption. Its increasing degree - often stimulated by marketing instruments - suctioned production and, in consequence, accelerated natural resources depletion, the natural environment pollution, and climate warming processes (Karczewska, 2016, pp. 39-41). It is possible, and at the same time advisable, that the change that now happens 
will lead to the abandonment - or at least limitation in scope - of the economy based on consumerism and to the transition to a closed loop economy. ${ }^{2}$ As the nature of management changes, what also changes is how we perceive and evaluate management (epistemological aspect). Economic globalization should respect the requirements of the closed circulation of resources, goods, and waste. There arises a need for a new analysis and critical evaluation of systems of production of consumer and investment goods around the world. Moreover, we should probably study the efficiency of economic units and the wealth of nations in a different manner (the methodological aspect). Therefore, the indicated circumstances should imply shifts both in the subject of economic sciences' research interests and in the methodology of scientific research. These are extremely important, current, and real challenges for ES.

\section{DEVELOPMENT ECONOMICS}

Development economics emerged after the Second World War and responded to rapidly progressing decolonization. This branch of economic sciences has a significant quantitative output: over three hundred conceptions. We may divide development economics into three groups, assuming the primacy of the factors on which their theoretical construction was established. ${ }^{3}$ Neoliberal theories search for the causes of underdevelopment in the internal factors of a country, Marxist and socialist theories blame external factors - mainly colonialism and imperialism - while dependency theories explain underdevelopment with both internal and external factors.

The qualitative significance of development economics should be perceived primarily in its comprehensive and objective diagnosis - as a whole and not in individual veins - of the causes of underdevelopment in this group of countries. Unfortunately, development economics is yet to formulate appropriate universal recommendations in the form of a corrective economic program that would be verifiable in the long term. However, the orthodox implementation of recommendations derived from these three groups of theories often ended up only deepening the underdevelopment of a country in which such attempts were made (Stiglitz, 2007; Deszczyński, 2015). 
The collapse of the Washington Consensus coincided with the appointment in 2008 of Justin Yifu Lin as the Vice President of the World Bank and its Chief Economist. Following Joseph Eugen Stiglitz, he used this situation to disseminate his scientific output, proposing "new structural economics" as a panacea for underdevelopment problems (Lin 2011). The undeniable advantage of new structural economics is that it draws the right conclusions from structuralists' mistakes (Lin, Wang, 2018). However, its disadvantage lies in its formulation in a selective and ex-post manner based on the experience of Asian countries' industrialization and - like do all structuralists - its special emphasis on the key role of state institutions in development processes, which is difficult in the conditions of the "soft state" syndrome commonly found in developing countries, if not impossible.

For developing countries, the Covid-19 pandemic means that the Western attention will not be on eliminating or - at least - alleviating the economic underdevelopment of these countries but on eliminating the economic effects of the pandemic; that is, Western countries focus on their internal problems, especially including the assurance of the broadly understood security of their societies and economies. This is likely to result in a freeze or even reduction of funds allocated to developing countries for development assistance and foreign direct investments, not to mention the possible limiting of trade relations. Most developing countries will be unable to overcome their economic underdevelopment without Western support. Thus, what is possible is the petrification and aggregation of problems that stem from underdevelopment.

It is impossible to solve developing countries' problems only with economic calculus, theories of development economics, or economists' knowledge and experience. What is needed here is an interdisciplinary approach and an awareness of the existence of Eurocentric burdens that effectively prevent the development of solutions adequate to the economic, political, and social realities of underdeveloped countries. Changes in the right direction were initiated by the Millennium Declaration, the Paris Declaration, the Accra Forum findings, and the Sustainable Development Goals. There is an increasing tendency to promote not only economic growth but also socioeconomic development, with a focus on raising the quality of life and 
combating poverty among the inhabitants of developing countries. An example of this is the 2019 Nobel Prize awarded to Abhijit Banerjee, Ester Duflo, and Michael Kremer, for their experimental approach to alleviating global poverty. This is what the change in the ontological aspect of development economics is all about.

Given the vagueness of how to remedy the presented situation, an important field of research opens also in economic sciences. The existing implementation of development economics theory in the practice of economic life of developing countries showed the inadequacy of proposed normative solutions, which are mostly standardized across a relatively large group of countries characterized by a strong diversity. In this situation, it may be more helpful to emphasize more the descriptive-explanatory approach that seeks to formulate a correct diagnosis of the economic situation of individual countries, among which almost all have their unique characteristics associated with political, social, historical, and cultural conditions. As a result, we must decide and solve problems under conditions of considerable uncertainty and the presence of many internal and external factors characterized by high volatility. This specificity makes the pragmatic approach - e.g. with the case study method supplemented by the triangulation method - more effective than the development economics theory, which a priori introduces a certain schematicism in the perception of reality (Serra, Stiglitz, 2008; Rodrik, 2015). We need patient long-term actions aimed at eliminating the three types of dualisms that appear in developing countries: economic, social, and political.

The symptoms of a change in perception and, consequently, in preferred research methods in development economics is visible for some time now. Above all, there is a growing recognition of the postulate by representatives of the institutional school that economic development should be understood primarily as a cultural process and not as the result of the influence of "the invisible hand" (Street, 1987, p. 1861). Equally strongly promoted is the view of economic development through the prism of "sustainable development." As its key components, this concept assumes economic development and the fight against income inequalities. Income inequalities quickly turn into wealth inequalities, resulting from the polarization of income and assets, access to education, and health care. These elements deepen the polarization 
of living standards among citizens of different countries (Dalevska, et al., 2019, pp. 1840-1841). As a result, many recommend recognizing these changes and shift the focus in economic sciences' research interests, but also to modify the practiced methodological choices. This means changing the epistemological and methodological aspects of economic sciences.

\section{CONCLUSION $^{4}$}

With this article, we intended to indicate the need for a serious reflection on the contents of ES sciences. Our reflection assumes only outlining problems and sketching argumentations that justify the change/revision in approach and content of these sciences. Real economic processes, economic policy, and business management methods prove since long that our civilization seems to be heading for a dead end. The wall with which humanity is about to painfully collide already appeared at the turn of the century with the dotcom bubble, the 2008 global financial crisis, repeated social protests against the growing stratification of income and wealth, increasingly frequent natural disasters resulting from the devastation of the environment and global warming, and now the global economic crisis provoked by the Covid-19 pandemic. Crises often stimulate new ideas and falsify old views. Mainstream economics and the management principles and guidelines derived from it at the global, macro, meso, and micro levels prove not fully effective. Therefore, it is reasonable to ask what and why should change in the area for which economists are responsible?

The above overview and discussion lead us to conclusions that are only a signal of the necessary reflection. Nevertheless, changes in economic practice and policy have already been announced (the ontological aspect), fundamental values and principles of management and the possibilities of their scientific cognition are perceived differently (the epistemological aspect), and there appear new demands of methods in economic activity research (the methodological aspect). First, we advocate cooperation between science, politics, and business, and we oppose the cynical use of each other to justify arbitrary views and pursue particularist interests. This will allow for the ideological 
neutrality of economic sciences and - in the long run - the strengthening of its prestige. Second, we propose posit that it is untenable to refer in the axiological sphere to the consequences of perceiving each person as homo economicus, especially in the radical version of the notion. Of course, elements of rationality and egoism are probably inherent attributes of humanity, but at the same time they cannot and should not be denied the characteristic of responsibility. Third, we prompt the inclusion of ethical values in the set of management imponderables. The problem of including these values in the standard model of rational choice has long been discussed among economists. There appear postulates to develop a model of homo economicus moralis not so much by supplementing the concept of rational choice but by its significant modification e.g. with the concept of rational compliance with norms or the concept of meta-ranking of preferences (Wincewicz-Price, 2016, pp. 435-458). The understanding and postulates of economic sciences toward the practice of business management should finally be liberated from the influence of at least some ideas of economic orthodoxy. In particular, the evaluation of top management's performance should cease to exclusively rely on the philosophy of managing on behalf of shareholders and with EVA. The vicious cycle of pursuing ever greater wealth for owners through ever greater production driven by excessive consumption should be broken if ecological, climatic, and civilizational risks are taken seriously. Many aptly believe that it is reasonable to include factors related to security and business agility in such an evaluation system. A consequence of accounting for business management agility with the EVA measure resides also in the drive to build extremely distributed and modularized international supply chains or, more broadly, specialize in international economic cooperation. Security requires reconsidering the validity of such a practice. We mean here not only security in the sense of ensuring economic continuity but also security in the sense of protecting nature and the climate. Economists must urgently coordinate international - or, rather, global - regulations concerning not only the above issues but also labor law, social security, education, or environmental protection. Jointly, these issues demand a different approach to the concepts of shaping the competitiveness of both nations and companies. In addition to the already developed mechanisms of competitiveness in the form of 
sectoral adjustments and the creation of innovation, it seems only reasonable to account for cultural mechanism. Economists usually cannot break away from the equilibrium metaphor as an instrument for explaining and deriving recommendations for economic processes. Of course, equilibrium can be a useful heuristic tool in economics deliberations, but other metaphors that illuminate the studied phenomena from different angles - and thus enrich the methodical workshop and knowledge of economic sciences representatives - should not be overlooked. An even more serious problem is the search for the correct measure of national wealth. So far, the commonly used measure is GDP, which is known to have a plethora of imperfections. The argument that nothing better has been invented so far is difficult to accept. After all, many alternative solutions have already appeared in this field, and they should finally be considered seriously. Another topic for discussion is the economic meaning of globalization. Gathered experiences show that globalization is not just a source of benefits. Theorists should conceptually confront the emerging processes of deglobalization and slowbalization. Last but not least important is the problem of the increasingly dangerous process of uneven distribution of wealth in the world. This is the domain of development economics, whose postulates have long proved ineffective. Moreover, it is right now when there appears a chance to take a closer look at the mechanism of rotation of metropolises and peripheries.

We realize that they we barely hint at the need to modernize the contents and methods of economic sciences. It seems that the pandemic crisis is the last straw that breaks the camel's back - a camel that already bears ignorance and hypocrisy - and it also is a motivating factor to intensify cognitive efforts. We deem it preferable to begin with an inventory of achievements, deficiencies, and new ideas of economic sciences.

Finally, we recognize that our analysis above is not free from numerous limitations. First, some of the issues raised have been stirring the emotions of scientists, intellectuals, and journalists for a long time, and it is not certain whether the Covid-19 pandemic will change their attitude, which seems to be the sine qua non condition for change. Second, the list of issues for modification/revision is much longer than the one presented above, and we hope that it will be expanded by others, encouraged to participate in the discussion 
we propose. Third, paradoxically, the magnitude of potential changes - both in real economic life and in science, including economic sciences - can be expected to be proportional to the duration of the pandemic. The relatively rapid containment of the pandemic seems to foster the eventual undertaking of relatively minor adjustments to economic sciences, while its prolonged duration may trigger more radical transformations in how economic sciences perform its descriptive, explanatory, and normative functions. 


\section{REFERENCES}

Al-Rodhan, N. R. F., Stoudmann, G. (2006)., Definitions of Globalization: A Comprehensive Overview and a Proposed Definition, Geneva: Geneva Center for Security Policy.

Banaszyk, P., Deszczyński, P., Gorynia, M., Malaga, K. (2021a). Przesłanki modyfikacji wybranych koncepcji ekonomicznych na skutek pandemii COVID-19. Gospodarka Narodowa. The Polish Journal of Economics, 1(305), 53-86. http://doi.org/10.33119/ GN/132485

Banaszyk, P., Deszczyński, P., Gorynia, M., Malaga, K. (2021b)., The Covid-19 pandemic as a potential change agent for selected economic concepts. Entrepreneurial Business and Economics Review, 9.

Bhagwati, J. (2004). In defence of globalization. Oxford University Press, Oxford.

Colander, D. et al. (2003)., The Changing Face of Mainstream Economics, Middlebury College Economics Discussion Paper no. 03-27, http://www.middlebury.edu/ econ (16.11.2020).

Creshwell, J. W., Creshwell, J. D. (2018). Research Design: Qualitative, Quantitative, and Mixed Methods Approaches. Sage Publications, Los Angeles, California.

D'Aveni, R. (1995). Coping with Hypercompetition: Utilizing the New 7S's Framework, Academy of Management Executive, no. 9, pp. 45-57.

Dalevska,et al. (2019). A model for estimating social and economic indicators of sustainable development, Entrepreneurship and Sustainable Issues, vol. 6, no. 4, June.

Deszczyński, P. (2001). Kraje rozwijające się w koncepcjach ekonomicznych SPD. Doktryna i praktyka. Wydawnictwo AE. Poznań.

Deszczyński, P. (2015). Nauki ekonomiczne wobec problemów globalizacji gospodarki światowej - implikacje dla krajów rozwijających się, in: Nauki ekonomiczne. Stylizowane fakty a wyzwania współczesności. ed. B. Fiedor, PTE, Warszawa.2015.

Disaster management, https://www.paho.org/disasters/index.php?option=com_docman\&view=download\&category_slug=tools\&alias=543-pandinflu-leadershipduring-tool-16\&Itemid=1179\&lang=en (12.7.2020).

Dzikowska, M. (2017). Delokalizacja a konkurencyjność przedsiębiorstw, Wydawnictwo Uniwersytetu Ekonomicznego w Poznaniu. Poznań.

Dzionek-Kozłowska, J. (2018),. Model homo economicus. Geneza, ewolucja, wpływ na rzeczywistość gospodarcza, Wydawnictwo Uniwersytetu Łódzkiego. Łódź.

Editor's note. (2020)., The COViD-19 Pandemic Is Forcing a Rethink in Macroeconomics. The Economist, July 25.

Fiedor, B. (2018). http://www.pte.pl/pliki/2/1/autoryzowany_stenogram_14_ marca_2018_2805.pdf (25.07.2020).

Fiedor, B. (2019). Podział na ortodoksje i heterodoksje w świetle potrzeby pluralizmu metodologicznego w ekonomii, perspektywa mikroekonomiczna, in: Ewolucja nauk 
ekonomicznych. Jedność a różnorodność. Relacje do innych nauk. Problemy klasyfikacyjne, ed. M. Gorynia, Polska Akademia Nauk, Komitet Nauk Ekonomicznych. Warszawa.

Friedman, M. (1953). The Methodology of Positive Economics, in: Essays in Positive Economics. Chicago University Press, Chicago.

Gorynia, M. (2019a). Współczesne nauki ekonomiczne - tożsamość, ewolucja, klasyfikacje, in: Ewolucja nauk ekonomicznych. Jedność a różnorodność. Relacje do innych nauk. Problemy klasyfikacyjne, ed. M. Gorynia. Polska Akademia Nauk. Warszawa.

Gorynia, M. (2019b). Czy nowy pragmatyzm jest pragmatyczny? in: Ekonomia i polityka.

Wokół Teorii Grzegorza W. Kołodko. ed. E. Mączyńska, Wydawnictwo Naukowe PWN. Warszawa.

Gorynia, M. (2019c). Competition and Globalisation in Economic Sciences: Selected Aspects, Economics and Business Review, vol. 5(19), no 3, pp. 118-133.

Gorynia, M. (2020). Przyszłość globalizacji, Rzeczpospolita, May 7, A21.

Gorynia, M. (2021). Will COVID-19 Kill Globalization? In: Covid-19 and International Business.Change of Era, eds. M. A. Marinov, S. T. Marinova, Routledge, London. Gupta S.G. (2015), Comparative Advantage and Competitive Advantage: An Economic Perspective and a Synthesis, Athens Journal of Business and Economics, vol. 1, no. 1, pp. 9-22.

Hume, D. (1969). A Treatise of Human Nature. Clarendon Press (1st ed. reprint). Oxford. Karczewska, A. (2016). Globalizacja i konsumpcjonizm jako uwarunkowania zmian i potencjalne źródła zagrożeń w sferze pracy. Zeszyty Naukowe Politechniki Częstochowskiej: Zarządzanie, vol. 2, no. 24. Częstochowa.

Kołodko, G. (2014). Nowy Pragmatyzm, czyli ekonomia i polityka dla przyszłości. Ekonomista, no. 2, pp. 161-180.

Kołodko, G. (2020a). Teoria wszystkiego nie istnieje, Rzeczpospolita, 23 października. Kołodko, G. (2003). Globalizacja a odrabianie zaległości rozwojowych, In: Globalizacja, marginalizacja, rozwój, ed. G. Kołodko. Warszawa.

Kołodko, G. W. (2020b). Ekonomia nowego pragmatyzmu: tożsamość, cele, metoda. Ekonomista, no. 2, pp. 181-205.

Kowalski, T. (2013). Globalization and transformation in Central European countries: The case of Poland. Poznan University of Economics Press.

Krugman, P. (2020). Arguing with Zombies: Economics, Politics, and the Fight for a Better Future. W.W. Norton \& Company. New York.

Lankford, W., Parsa F. (1999). Outsourcing a Primer, Management Decision, vol. 37, no 4, pp. 310-316.

Lin, J. Y., Wang, X. (2018)., The Facilitating State and Economic Development: The Role of the State in New Structural Economics, in: New Structural Policy in an Open Market Economy. eds. J. Y. Lin, A. Z. Nowak. Wydawnictwo Naukowe Wydziału Zarządzania Uniwersytetu Warszawskiego. Warszawa. 
Lin, J. Y. (2011). New Structural Economics: A Framework for Rethinking Development, The World Bank Research Observer, vol. 26, no. 2, Washington. D. C.

Lipowski, A. (2011). Z metodologii nauk ekonomicznych: struktura logiczna ujęcia pozytywnego i normatywnego, Ruch Prawniczy, Ekonomiczny i Socjologiczny, YB 73, b. 2, pp. $195-217$.

Marsewicz, A. (2020). Jak zmieni się łańcuch dostaw z powodu wpływu Covid-19?, eLogistyczny. http://e-logistyczny.pl/zmieni-sie-lancuch-dostaw-powodu-wplywucovid-19-2020-05-26-835 (12.07.2020).

Mentzer, J. et al. (2003). Defining supply chain management. Journal of Business Logistics, vol. 22, no 2, pp. 1-25.

Mitschke, A. (2008). The Influence of National Competition Policy on the International Competitiveness of Nations: A Contribution to the Debate on International Competition Rules. Springer Science \& Business Media. Berlin.

Pichlak, M. (2018). Gospodarka o obiegu zamkniętym model koncepcyjny. Ekonomista, no. 3 .

Porter, M. (2011). Competitive Advantage of Nations: Creating and Sustaining Superior Performance. Simon and Schuster. New York.

Rifkin, J. (2016). Społeczeństwo zerowych kosztów krańcowych. Wydawnictwo Studio Emka, Warszawa.

Robbins, L. (1932). An Essay on the Nature and Significance of Economic Science. Macmillan, London.

Rodrik ,D. (2011). The Globalization Paradox: Democracy and the Future of the World Economy. Norton and Company, New York.

Rodrik, D. (2017). Populism and the Economics of Globalization. AIB Conference. Dubai.

Rodrik, D. (2015). Economics rules: Why economics works, when it fails, and how to tell the difference. Oxford: Oxford University Press.

Serra, N., Stiglitz J. E., eds. (2008)., The Washington Consensus Reconsidered: Toward a New Global Governance. Oxford University Press.

Sławińska, M. Witczak H. eds. (2008). Podstawy metodologiczne prac doktorskich w naukach ekonomicznych. PWE. Warszawa.

Snyder, L., Shen, Z. J. (2019). Fundamentals of Supply Chain Theory. John Wiley \& Sons, Hoboken.

Solarz, J., Waliszewski, K. (2020). Całościowe zarządzanie ryzykiem systemowym. Pandemia Covid-19, edu-Libri. Warszawa-Legionowo.

Stiglitz, J. E. (2002)., Globalization and its Discontents . W.W. Norton Company. Washington.

Stiglitz, J. E. (2007). Globalizacja. Wydawnictwo Naukowe PWN. Warszawa.

Stiglitz, J. E. (2007). Wizja sprawiedliwej globalizacji. Wydawnictwo Naukowe PWN. Warszawa.

Street J. (1987). The Institutional Theory of Economic Development, Journal of Economic Issues, vol. 21, no. 4, December. 
Streeten, P. (2001). Globalisation: Threat or opportunity? Copenhagen: Copenhagen Business School Press.

Trocki, J. (1999). Outsourcing jako metoda restrukturyzacji przedsiębiorstw Gospodarka Materiałowa i Logistyka, no. 9: 181-183.

Walas-Trębacz, J. (2007).Uwarunkowania i skutki procesu globalizacji, In: Marketing, ed. Surówka-Marszałek W. Wydawnictwo Krakowskiego Towarzystwa Edukacyjnego. Kraków.

Wilkin, J. (2016). Instytucjonalne i kulturowe podstawy gospodarowania. Humanistyczna perspektywa ekonomii. Wydawnictwo Naukowe Scholar. Warszawa.

Wincewicz-Pric,e A. (2016). Homo economicus moralis - ekonomiczne analizy zachowań moralnych, in: METAEKONOMIA. Zagadnienia z filozofi ekonomii, eds. M. Gorazda, Ł. Hardt, T. Kwarciński, Kraków.Wydawnictwo Copernicus Center Press. Kraków.

Witkowski, J. (2010). Zarzadzanie łańcuchem dostaw. Koncepcje, procedury, doświadczenia. Polskie Wydawnictwo Ekonomiczne. Warszawa.

Zahn, J. et al. (2020). Globalne łańcuchy wartości zmieniają się w regionalne, Obserwator Finansowy.pl, https://www.obserwatorfinansowy.pl/tematyka/makroekonomia/trendy-gospodarcze/globalne-lancuchy-wartosci-zamienia-sie-w-regionalne/ (14.11.2020).

\section{ENDNOTES}

[1] This publication refers to the article by Banaszyk, P., Deszczyński P., Gorynia, M., \& Malaga, K. (2021a) - it uses modified selected fragments of this text.

[2] The linear economic process begins with the consumption of raw materials, goes through the production of consumer and investment goods - necessary to increase consumption - and finally leads to consumption that generates waste, while often realizing not utilitarian but prestige values. A closed loop economy generates two streams: biological and technical. Thanks to the former, organic waste is directed back to the environment, thus accelerating its regeneration, and thanks to the latter, technical waste is recycled, utilized, or reused. (Pichlak, 2018: 335-336).

${ }^{[3]}$ For more on this subject, see Deszczyński (2001).

[4] As noted at the beginning this article discusses four sample research areas from ES: global supply chains, international competitiveness, globalization and development economics. The conclusions presented in this point are, however, broader and more complete, as they refer to the opinions contained in the text Banaszyk, P., Deszczyńsk, P., Gorynia, M., \& Malaga, K. (2021a). The basis for their formulation was the analysis of eight sample issues presented in the above article. These examples were: homo economicus, business performance, global supply chains, international competitiveness, economic equilibrium, the essence and measurement of national wealth, globalization, and development economics. The first four issues are discussed in more detail in the publication:Banaszyk P., Deszczyński P., Gorynia M. \& Malaga K (2021b). 
